\title{
DESACATO EN EL CÓDIGO DE JUSTICIA MILITAR: UN INEXPLICABLE OLVIDO EN EL DEBATE DEMOCRÁTICO*
}

\author{
Germán Echeverría Ramírez**
}

\begin{abstract}
RESUMEN
Los delitos descritos en los artículos 283 y 284 del Código de Justicia Militar castigan a quienes ofenden de palabra o por escrito a las Fuerzas Armadas, a sus integrantes, a guarda o centinela y, en estricto rigor, corresponden a figuras de desacato a la autoridad, análogas a las derogadas hace ya años de la Ley de Seguridad Interior del Estado y del Código Penal, atendida su manifiesta colisión con la garantía que entiende a la libertad de expresión como uno de los más eficaces controles al ejercicio del poder público. Las serias dificultades para armonizar estas formas de desacato con el respeto a los derechos humanos han convertido a estos delitos de la legislación militar en un verdadero arcano jurídico, no sólo para las nuevas generaciones de abogados, sino también para la comunidad nacional que de paso, con su silencio, parece aceptarlos como integrantes de la institucionalidad democrática.
\end{abstract}

DESACATO - DELITO MILITAR - DEMOCRACIA

\section{Contempt in the military justice code: an inexplicable oversight in a democratic debate}

\begin{abstract}
The crimes established in articles 283 and 284 of the Chilean Military Justice Code punish whoever offends the Armed Forces, by word or by writing, and in strict sense they are types of contempt towards authority, analogous to those derogated years ago from the State's Internal Security Act and the Criminal Justice Code, because of their contrast with the right of free expression, as one of the most efficient controls over the exercise of public power. These crimes towards military legislation have turned into a true legal fossil due to the difficulty to harmonize these means of contempt for respect towards buman rights, not only for new generations of attorneys, but also for the national community, who whose silence seem to accept them as part of democratic institutionalization.
\end{abstract}

\section{CONTEMPT - MILITARY CRIME - DEMOCRACY}

* Este Artículo surge de la propuesta que realizara la Unidad de Estudios de la Defensoría Regional de Los Lagos a la Comisión de Estudios Constitucionales de la Defensoría Nacional para incorporar este tema a la agenda de materias susceptibles de ser eventualmente sometidas al control del Tribunal Constitucional. El autor agradece especialmente al Centro de Documentación de la Defensoría Nacional el apoyo que prestó a este trabajo de investigación.

** Abogado y periodista, profesional de la Unidad de Estudios de la Defensoría Regional de Los Lagos, Décima Región, Chile. gecheverria@dpp.cl. Artículo recibido el 19 de marzo de 2009 y aceptado para su publicación por el Comité Editorial el 18 de mayo de 2009. 
$\mathrm{U}$ n olvido en el proceso legislativo ${ }^{1}$ que durante la presente década derogó los delitos de desacato a la autoridad en su modalidad de injurias sería, por ahora, una de las anodinas explicaciones para justificar la vigencia de los artículos 283 y 284 del Código de Justicia Militar, ${ }^{2}$ normas que, a pesar de la evolución normativa, mantienen incólume el peligro de persecución penal pública de todos quienes se atrevan a emitir opiniones que pudieren ofender a las Fuerzas Armadas ${ }^{3}$ o alguno de sus integrantes.

Debido a su franca colisión con los valores de una organización políticamente democrática, ${ }^{4}$ estas figuras destinadas a tutelar bajo amenaza penal el honor del Estado en Armas y de sus miembros deberían preocupar a los glosadores del derecho antes que ocupar a los operadores del sistema de pesquisa penal pública.

$Y$ es que tipos penales análogos a los descritos han sido ya expresamente derogados de nuestra legislación. Así, por ejemplo, el antiguo delito de desacato del Artículo $6 \mathrm{~b}$ de la Ley de Seguridad Interior del Estado fue suprimido el año $2001^{5}$ mediante la llamada Ley de Prensa y las figuras equivalentes contenidas en los artículos 263 y 264 del Código Penal y 417 del Código de Justicia Militar fueron abolidas el año 2005 a través de las leyes $\mathrm{N}^{\text {os }} 20.048$ y $20.064,{ }^{6}$ razón por la cual no se entiende la subsistencia de la especial protección penal pública que nuestro ordenamiento preserva hacia el honor de los institutos armados y de sus integrantes.

${ }^{1}$ Ley $\mathrm{N}^{\circ} 19.733$, Ley $\mathrm{N}^{\circ} 20.048$ y Ley $\mathrm{N}^{\circ} 20.064$ publicadas entre los años 2001 y 2005 derogaron de distintos cuerpos legales los delitos de desacato a la autoridad en su modalidad de injurias.

${ }^{2}$ Artículo 283 del Código de Justicia Militar: El que amenazare u ofendiere con palabras o gestos a centinela, guarda o fuerza armada, será castigado con la pena de prisión en su grado máximo a reclusión menor en su grado mínimo. Pero si el hecho se efectuare en campaña, la pena se elevará uno o dos grados. Artículo 284 del Código de Justicia Militar: El que amenazare en los términos del Artículo 296 del Código Penal, ofendiere o injuriare de palabra o por escrito o por cualquier otro medio a las Fuerzas Armadas, sus unidades, reparticiones, armas, clases o cuerpos determinados, o a uno de sus integrantes con conocimiento de su calidad de miembro de esas instituciones, será sancionado con la pena de presidio menor en su grado mínimo a medio.

${ }^{3}$ El Artículo 101 de la Constitución Política del Estado dispone que las Fuerzas Armadas dependientes del Ministerio encargado de la Defensa Nacional están constituidas única y exclusivamente por el Ejército, la Armada y la Fuerza Aérea. Existen para la defensa de la patria y son esenciales para la seguridad nacional.

${ }^{4}$ Sobre este punto, la Comisión Interamericana de Derechos Humanos en su informe anual de 1994 ha planteado que la aplicación de las leyes de desacato destinadas a proteger el honor de los funcionarios públicos -que actúan en carácter oficial- les otorga injustificadamente un derecho a la protección del que no disponen los demás integrantes de la sociedad. Esta distinción invierte directamente el principio fundamental de un sistema democrático que hace al gobierno objeto de controles, entre ellos, el escrutinio de la ciudadanía, para prevenir o controlar el abuso de su poder coactivo.

${ }^{5}$ El 4 de junio de 2001 se publicó la Ley Nº 19.733 conocida como Ley de Prensa que derogó de la Ley de Seguridad Interior del Estado el Artículo 6 b) que contenía figuras agravadas de desacato y que castigaba como delitos contra el orden público y la integridad del Estado la injuria, la calumnia y la difamación contra altas autoridades de la Nación.

${ }^{6}$ El 31 de agosto y 29 de septiembre del año 2005 se publicaron también las leyes 20.048 y 20.064, la primera de las cuales derogó la figura de desacato en su modalidad de injurias y calumnias del Código Penal y la segunda ajustó a esos términos el Artículo 417 del Código de Justicia Militar que castigaba penalmente al que ofendiere o injuriare de palabra o por escrito o por cualquier otro medio a funcionarios de Carabineros e Investigaciones. 
A la hora de intentar comprender por qué subsiste esta forma de desacato en nuestra legislación, hay otras explicaciones más agudas que el simple olvido legislativo. Especialistas, vinculados al ámbito de los derechos humanos, ${ }^{7}$ desconocen por qué no se incluyeron estos delitos en el conjunto de normas que derogaron el desacato en Chile, aunque sugieren algunas explicaciones asociadas a la dinámica de transición democrática de los últimos tres lustros que, de facto y con limitadas excepciones, ha preservado una suerte de intangibilidad de la jurisdicción militar, cuyo antecedente más elocuente fue su exclusión del debate y posterior aplicación de la reforma procesal penal.

Se trata de un diagnóstico compartido por el director para América de Human Rights Watch, José Miguel Vivanco, quien públicamente ha sostenido que en Chile el tema de la justicia militar es una asignatura pendiente. "En eso ha habido algo de negligencia. Es un tema que ha caído en el radar de lo secundario. No es un tema prioritario". 8

Sin embargo, el principal cuestionamiento que formulamos a la subsistencia del desacato en su vertiente de injurias y ofensas a las Fuerzas Armadas y sus agentes, no es sólo el tribunal competente para juzgarlo y sus reglas de procedimiento, sino también la ineptitud de los delitos descritos en los artículos 283 y 284 del Código de Justicia Militar para convivir con las garantías fundamentales que limitan el ejercicio de la soberanía, especialmente la referida a la libertad de expresión como la principal fuente de control al ejercicio del poder público.

Lo anterior, sin perjuicio de las interrogantes surgidas en torno de la fragilidad conceptual de esta especie de desacato, cuyo ethos y thelos descansa, por ejemplo, en la discutible pretensión del Artículo 284 del Código de Justicia Militar de amparar el honor de las Fuerzas Armadas, en circunstancias que las injurias y ofensas a que hace referencia esta forma de desacato son inadecuadas para proteger al Estado como persona jurídica y sólo serían capaces de conminar criminalmente los atentados contra el buen nombre y reputación de hombres y mujeres.

Así, por lo demás, lo plantea el profesor Jorge Mera, quien escribe que, en efecto, constituye delito injuriar a las Fuerzas Armadas y a Carabineros 9 o a sus unidades o reparticiones, en circunstancias que el sistema de protección penal del honor en nuestra legislación tutela la honra de las personas naturales y no la de las instituciones o la de personas jurídicas. Se trata, pues, de una discriminación a favor de las Fuerzas Armadas. ${ }^{10}$

${ }^{7}$ Por ejemplo, los abogados y académicos Felipe González y Domingo Lovera.

${ }^{8}$ Vivanco, J. M. "Hay Jueces que se resisten a terminar con el secretismo", La Nación.cl, domingo 25 de diciembre de 2005. http://www.lanacion.cl/prontus_noticias/site/artic/20051224/pags/20051224160126.html

${ }^{9}$ El 29 de septiembre del año 2005 se publicó la Ley 20.064 que derogó del Artículo 417 del Código de Justicia Militar el reproche penal para quien ofendiere o injuriare de palabra o por escrito o por cualquier otro medio a Carabineros, sin incluir modificación alguna al Artículo 284 del mismo texto que, en consecuencia, mantiene vigente el delito de desacato a las Fuerzas Armadas.

${ }^{10}$ Mera, J., "Razones justificatorias y ámbito de la jurisdicción penal militar en tiempo de paz", en Mera Figueroa, J. (Editor), Justicia militar y estado de derecho, Cuadernos de Análisis Jurídico de la Universidad Diego Portales, Santiago, 1998. 
Precisamente, en torno a estos asuntos girarán las preguntas a las que se intentará dar respuesta en este artículos: ¿Cuál es la naturaleza y el tribunal competente para conocer de los delitos de los Artículos 283 y 284 del Código de Justicia Militar?, ¿se trata de figuras en agonía?, ¿vulneran la garantía que asegura la libertad de expresión?

\section{JuRisdicción militar y DESACATO a las FuerZas ARMAdas}

Un análisis de la legislación comparada revela que la jurisdicción militar chilena es casi con seguridad la de mayor extensión de occidente. No sólo porque tiene potestades para conocer y resolver delitos especiales, cuyo bien jurídico tutelado está efectivamente asociado al orden castrense, sino también por las expresas facultades que se le han concedido para conocer de delitos comunes y para actuar indistintamente en tiempos excepcionales de guerra, como también durante la época de paz que rige el normal funcionamiento de las instituciones civiles.

María Inés Horvitz ${ }^{11}$ sostiene que a nivel del derecho comparado existen jurisdicciones militares de carácter excepcional, acotadas a una competencia que opera sólo en época de guerra; otras intermedias, que confían a su conocimiento y fallo algunos delitos contra la seguridad del Estado y, por último, modelos amplios, como el chileno, que encomiendan a esta justicia, de fuero marcial, la resolución de delitos comunes cometidos por civiles.

Es así como nuestra jurisdicción penal militar ha sido calificada por la doctrina como amplísima, adjetivo que precisamente es invocado por Renato Astrosa para describirla y sostener que de acuerdo al Artículo 5 del Código de Justicia Militar comprende:

${ }^{11}$ Horvitz, M. I. "La justicia militar: justificación, competencia y organización en el derecho comparado. Los principios de independencia e imparcialidad en la organización de los tribunales militares chilenos", en Mera Figueroa, J. (Editor), Justicia militar y estado de derecho, Cuadernos de Análisis Jurídico de la Universidad Diego Portales, Santiago, 1998, pp. 79-80. Sostiene que a nivel comparado existen: "Sistemas que contemplan la existencia de tribunales militares con jurisdicción militar excepcional, es decir, únicamente para tiempos de guerra o sobre FF.AA. estacionadas fuera del territorio nacional. Es el caso de Alemania, Francia, países nórdicos. En estos países los delitos militares cometidos en tiempo de paz son juzgados por los tribunales ordinarios.

Sistemas intermedios que admiten un fuero militar restringido a los delitos estrictamente del ámbito castrense cometidos por militares. Esta es la situación actual de Italia, Gran Bretaña o Estados Unidos. En el caso de España que, en principio pareciera pertenecer a este sistema, se han planteado cuestiones de constitucionalidad respecto de normas que atribuyen competencia a los tribunales militares para el enjuiciamiento de delitos cuyo sujeto activo no es propiamente un militar o donde se ha efectuado una asimilación a esa categoría en una interpretación que se ha considerado extensiva $e$ in malam partem, saliéndose del ámbito de lo estrictamente castrense.

En la línea de una mayor extensión del fuero militar existen países en que los civiles son juzgados excepcionalmente por tribunales militares, especialmente tratándose de delitos contra la seguridad del Estado, contra los cuerpos armados o contra el orden público. Es el caso de Argentina, Perú, Brasil, Uruguay y otros países latinoamericanos.

Sistema de jurisdicción militar amplio. En este sistema, de carácter extraordinario en el derecho comparado, la jurisdicción militar cubre no sólo los delitos militares propios, sino que además delitos comunes y políticos cometidos por militares y/o civiles que se "militarizan" ficticiamente para encuadrarlos dentro del fuero militar. Es el caso de Chile". 
a) Los delitos militares, reconociendo como tales todos aquellos contemplados en el Código de Justicia Militar y en otras leyes especiales que sometan el conocimiento de sus infracciones a los tribunales militares, agregando que es indudable que numerosísimos de estos delitos son impropiamente militares, ya que pueden perpetrarse por civiles.

b) Los delitos comunes cometidos por militares o empleados civiles de los cuerpos armados cuando concurre alguno de estos factores: 1) estado de guerra o estando en campaña (ratione temporis); 2) en acto del servicio o con ocasión del servicio (ratione legis); y 3) en un recinto militar (ratione loci).

c) Concurso de delincuentes y de delitos, comprendiendo dentro de la jurisdicción militar al civil que cometió un delito común conjuntamente con un militar que estaba en servicio; a civiles responsables de delitos comunes cuando alguno de éstos fuere conexo con un delito militar; y al militar por delitos del fuero común cuando además se le imputare un delito de jurisdicción militar, ${ }^{12}$ de conformidad a lo previsto en los artículos 11 y 12 del Código de Justicia Militar.

A lo anterior habría que agregar otro antecedente aportado por el mismo autor, quien sostiene que otra de las causas que explica la expansión de nuestra jurisdicción militar se debe a la promulgación de numerosas leyes, entre otras las de reclutamiento, navegación aérea, control de armas, seguridad de Estado, etc., que entregan el conocimiento de sus infracciones a los tribunales militares, por lo que esos delitos adquieren impropiamente el carácter de delitos militares. ${ }^{13}$

Los efectos de esta regulación son predecibles. Un estudio de las causas tramitadas en el Segundo Juzgado Militar de Santiago durante el período 1990-1996 demostró que de un total de 2.209 inculpados ante ese tribunal, más del $93 \%$ eran civiles. ${ }^{14}$

Luppy Aguirre ${ }^{15}$ sostiene que el motivo del alto número de civiles sometidos a la jurisdicción militar está dado por la cantidad de procesos originados en los enfrentamientos que se producen entre el mundo castrense y civil, los que en su mayoría se refieren a manifestaciones universitarias y eventos de alta concurrencia de público como recitales o encuentros deportivos. "Es así que la mayoría de las causas que tramita el

${ }^{12}$ Astrosa, R, Derecho Penal Militar, 2a ed., Ed. Jurídica de Chile, Santiago, 1974. pp. 27 y ss.

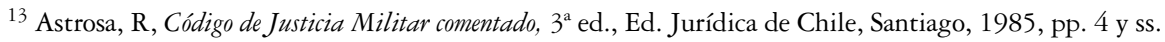

${ }^{14}$ Aguirre, L., Justicia militar. Una mirada en cifras, en Mera Figueroa, J. (Editor), Justicia militar y estado de derecho, Cuadernos de Análisis Jurídico de la Universidad Diego Portales, Santiago, 1998, p. 203.

${ }^{15}$ Estas afirmaciones las realizó como ayudante de investigación del Centro de Investigación de la Universidad Diego Portales, en cuya calidad le correspondió intervenir en un estudio empírico que comprendió una relación detallada de los procesos tramitados y terminados, en el período que va de enero de 1990 a abril de 1997, en el Juzgado de Aviación y el Segundo Juzgado Militar de Santiago, del que se excluyeron las causas seguidas por Reclutamiento, lo que habría elevado a más del doble el total de procesos revisados, atendido el elevado número de incumplimiento de esta carga legal. 
Juzgado Militar de Santiago son por ofensas a Carabineros y FF.AA...", 16, 17 escribe esta investigadora, quien precisamente efectuó un estudio empírico de las causas incoadas ante la justicia militar en el período 1990-1996.

En efecto, las actuaciones de la justicia militar distan de ser excepcionales y son consecuencia de la extensión de su competencia. Lo confirman las cifras que revelan que la gran mayoría de sus inculpados no viste uniforme y las aseveraciones de quienes atribuyen al sopor de la transición democrática una suerte de molicie legislativa, que sólo a paso cansino se atreve a recortar y reorientar su ejercicio hacia valores más propios de un Estado de Derecho de inspiración democrática y liberal.

Pero, además de la incuestionable evidencia acerca del desmesurado ámbito de conocimiento y decisión de la justicia militar, hay que reconocer también que esta incuestionable realidad se percibe aún más exacerbada fruto del generalizado desconocimiento de las normas que, tímidamente, han intentado atenuar esta verdadera inflación jurisdiccional de los tribunales castrenses. ${ }^{18}$

Por ejemplo, no deja de llamar la atención que cada vez que se habla del desacato del Artículo 284 del Código de Justicia Militar y su eventual inconstitucionalidad muchos abogados consideren este asunto como una cuestión estrictamente marcial y lo asocien automáticamente con la jurisdicción militar, ${ }^{19}$ como si se tratara de una materia ajena a la justicia ordinaria y que debiera, por lo tanto, permanecer hibernando en el congelador reservado a las reformas de fondo a las Fuerzas Armadas.

A juzgar por los comentarios recogidos durante esta investigación, hoy pocos recuerdan que las llamadas leyes Cumplido, ${ }^{20}$ publicadas a comienzos de los años 90, confiaron exclusivamente a los jueces civiles el conocimiento y fallo de las injurias y

${ }^{16}$ Estas causas deben haberse iniciado con anterioridad a febrero de 1991, fecha en la que entró en vigencia la Ley 19.047 que confió a la justicia ordinaria el conocimiento y fallo de las causas originadas en la infracción de civiles a lo prescrito en el Artículo 284 del Código de Justicia Militar. Es posible también que el efecto de la supresión de la denominada impropia competencia de los juzgados militares no haya sido pleno y la fuerza de la costumbre haya continuado sometiendo a fallo de los tribunales castrenses los desacatos en su modalidad de injurias cometidos por particulares contra las FF.AA. y sus miembros. Otro tanto debe corresponder a causas seguidas contra inculpados y procesados como autores o partícipes del delito previsto en el Artículo 283 del Código de Justicia Militar, el que hasta el día de hoy sigue considerándose un delito de exclusiva competencia de la jurisdicción marcial.

17 Vid. Aguirre, L., op. cit.

18 Por ejemplo, una de las denominadas leyes Cumplido, la No 19.047 de 14 de febrero de 1991, que sustrajo de la justicia militar el conocimiento y fallo de delitos denominados impropiamente militares como el desacato en su modalidad de injurias a las Fuerzas Armadas y Carabineros, para confiar en definitiva esa competencia a la justicia ordinaria.

${ }^{19}$ A nivel académico se ignora por qué el Artículo 284 del Código de Justicia Militar no se incorporó en los proyectos que dieron origen a las leyes 20.048 y 20.064 que derogaron de nuestra legislación el delito de desacato a la autoridad en su modalidad de injurias y todas las explicaciones recogidas lo atribuyen al desinterés político de intervenir el ámbito de competencia de la justicia militar, dejando entrever que esta forma de desacato es percibido dentro del catálogo de delitos que son de conocimiento de los tribunales castrenses y no como una materia confiada a la justicia ordinaria, dejando entrever un cierto olvido de las modificaciones incorporadas por las llamadas leyes Cumplido a la justicia militar.

${ }^{20}$ Por ejemplo, la Ley 19.029 de 23 de enero de 1991 y la Ley 19.047 de 14 de febrero de 1991. 
ofensas proferidas por particulares en contra de las Fuerzas Armadas, Carabineros o alguno de sus integrantes, ${ }^{21}$ con lo cual se suprimió de nuestra legislación una fracción de la impropia competencia de los juzgados militares, ${ }^{22}$ aun cuando se debe admitir que el conocimiento y fallo del desacato del Artículo 283 del Código de Justicia Militar continúa confiado al fuero castrense.

Sobre este punto, ilustrativo resulta recordar las palabras utilizadas por Jorge Molina Valdivieso, parlamentario comisionado por la Cámara de Diputados para presentar ante el Senado el proyecto que originó la Ley 19.047, una de las llamadas leyes Cumplido, que abolió una cuota significativa de la denominada competencia impropia de la jurisdicción militar en materia de desacato a las Fuerzas Armadas y Carabineros:

"En el Código de Justicia Militar, las modificaciones introducidas mediante el proyecto tienen por objeto establecer la eficacia jurídica del derecho militar; reducir la excesiva competencia de la jurisdicción militar; fijar penas proporcionales a los bienes jurídicos tutelados; proteger debidamente las garantías del imputado; eliminar ciertos privilegios en detrimento de los civiles, y otorgar inamovilidad y, por lo tanto, mayor independencia a la justicia militar. ${ }^{23}$

21 Artículo $2^{\circ}$ de la Ley 19.047, publicada el 14 de febrero de 1991: Introdúcense las siguientes modificaciones al Código de Justicia Militar: 2) Modifícase el Artículo 5º en la forma que se indica: a) Sustitúyese su número $1^{\circ}$, por el siguiente: “ $1^{\circ}$ De las causas por delitos militares, entendiéndose por tales los contemplados en este Código, excepto aquellos a que dieren lugar los delitos cometidos por civiles previstos en los artículos 284 y 417, cuyo conocimiento corresponderá en todo caso a la justicia ordinaria, y también de las causas que leyes especiales sometan al conocimiento de los tribunales militares".

Conocerán también de las causas por infracciones contempladas en el Código Aeronáutico, en el decreto Ley N $\mathrm{N}^{\circ}$ 2.306, de 1978, sobre Reclutamiento y Movilización y en la Ley Nº 18.953, sobre Movilización, aun cuando los agentes fueren exclusivamente civiles.

${ }^{22}$ Uno de los ámbitos que exhibe con mayor nitidez la subsistencia de la denominada impropia competencia de la jurisdicción militar es el de los llamados conflictos indígenas... "Los mapuches acusados de violencia contra la policía, así como los que han sido víctimas de la violencia o el maltrato policiales, comparecen, independientemente de que sean acusados o víctimas, ante tribunales militares... El contraste entre los procedimientos que se están aplicando abora en los tribunales penales ordinarios y el sistema anacrónico de la justicia militar es muy marcado en la Araucania, donde coexisten muy de cerca. Partiendo de la experiencia de los abogados que se han especializado en el litigio de casos de mapuches en tribunales militares, el Programa de Derechos Indígenas del Instituto de Estudios Indígenas de la Universidad de la Frontera ha descrito los obstáculos que plantea el sistema de justicia militar: Se trata de procesos muy largos, burocráticos, donde prácticamente no existe derecho a la defensa. Ello, porque el período de investigación es secreto y no existen instancias frente a las cuales hacer valer argumentos y evidencias, sino cuando ya se encuentra formada la convicción del juez. En la mayoría de los casos que involucran a mapuches, los Carabineros desarrollan una investigación interna que es considerada como parte del sumario y constituye un antecedente fundamental para el Fiscal y para el Juez. Esta investigación es realizada por el superior del (los) funcionario(s) involucrado(s), lo que afecta nuevamente la posibilidad de esclarecimiento de los hechos investigados, puesto que la condena eventual de uno o varios Carabineros por denuncias de torturas o malos tratos puede provocar un daño a la imagen institucional", escribe Marcela Rosen Murúa en la Revista Virtual Escaner Cultural, No 68, diciembre, 2004, Santiago. http://www.escaner.cl/escaner68/origen.htm.

${ }^{23}$ Molina, J., "Diario de Sesiones del Senado", Legislatura $321^{\text {a }}$ Extraordinaria, Sesión $11^{\text {a }}$, jueves 8 de noviembre de 1990, publicación oficial, Valparaíso. 
En ese orden de ideas, por unanimidad, la Cámara enmendó el Artículo $5^{\circ}$, referente a la competencia de los juzgados militares, reduciéndola significativamente a través de la eliminación de la denominada "competencia impropia"; vale decir, el juzgamiento de civiles. En lo sucesivo, los tribunales castrenses conocerán sólo las causas por delitos militares, entendiendo por tales los contemplados en el Código de Justicia Militar, con excepción de los cometidos por civiles y que están penados en algunos artículos, y que se refieren a violencia o maltrato a centinela, guardia o fuerza armada; amenaza, ofensa o injuria a las Fuerzas Armadas o a sus miembros y a Carabineros, casos en que conocerán los tribunales ordinarios". 24

En consecuencia, para determinar el tribunal competente que conocerá y resolverá los casos de desacato de los artículos 283 y 284 del Código de Justicia Militar hay que distinguir en atención al delito y a la calidad del sujeto activo del mismo:

a) Las ofensas o injurias cometidas por civiles en contra de las Fuerzas Armadas y sus integrantes, son de competencia de la justicia ordinaria.

b) El desacato contra las Fuerzas Armadas y sus integrantes, cometido por militares, ${ }^{25}$ es de conocimiento y resolución de la jurisdicción castrense vigente en tiempos de paz o de guerra, según corresponda.

c) Las ofensas cometidas por civiles y militares contra centinela, guarda o fuerza armada serán de competencia de los tribunales militares.

2. Contenido del desacato de los aRtículos 283 y 284 Del Código de Justicia Militar y COMPetenCia JuRisdiccional

Los artículos 283 y 284 del Código de Justicia Militar junto con sancionar penalmente las injurias y ofensas dirigidas a las Fuerzas Armadas y sus miembros, castigan también las amenazas proferidas en su contra, hipótesis esta última que no será objeto de análisis en el presente artículo, ${ }^{26}$ desde que el principal cuestionamiento de inconstitucionalidad

${ }^{24}$ Ibid, cita $\mathrm{N}^{\mathrm{o}} 20$.

${ }^{25}$ De acuerdo al Artículo $6^{\circ}$ del Código de Justicia Militar se considerarán militares los que se encuentren comprendidos en las leyes de planta o dotación del Ejército, Armada, Fuerza Aérea y Carabineros; los alumnos que efectúan los dos últimos años de estudios en las Escuelas Matrices para Oficiales de las Fuerzas Armadas, y los aspirantes a oficiales que integran los cursos de la Escuela de Carabineros; los Oficiales de Reclutamiento; los conscriptos; los miembros de las Fuerzas Armadas desde que sean llamados al servicio; las personas que sigan en campaña en el estado de guerra; y los prisioneros de guerra.

${ }^{26}$ Lo anterior, sin perjuicio de tener presente que la sentencia de la Corte Interamericana de Justicia que condenó al Estado de Chile en el caso Palamara Iribarne sostuvo que dicho tribunal nota con preocupación que, a pesar del valioso aporte de la reforma legislativa que pretendió derogar de nuestra legislación el desacato en su modalidad de injurias a la autoridad, se conserva en el Artículo 264 del Código Penal reformado un tipo penal de amenaza a las mismas autoridades que, con anterioridad a la reforma de dicho Código, constituían el sujeto pasivo del delito de desacato.

De esta manera, afirma el referido fallo de la Corte Interamericana, se contempla en el Código Penal una descripción que es ambigua y no delimita claramente cuál es el ámbito típico de la conducta delictiva de 
de ambas normas se dirige a sus descripciones de desacato, cometidas a través de expresiones proferidas o acciones ejecutadas en deshonra, descrédito o menosprecio ${ }^{27}$ de las ramas castrenses y de los militares. ${ }^{28}$

Cabe recordar que el Artículo $283^{29}$ considera autor de desacato al que ofendiere con palabras o con gestos a centinela, guarda o fuerza armada ${ }^{30}$ y agrava la pena si el hecho se cometiere en campaña. Es un tema pacífico que el tipo penal considera como sujeto activo tanto a civiles como a militares al utilizar la expresión "el que" y en el caso de los uniformados dicha calidad se erige en una circunstancia agravante de carácter objetivo, según lo previene el Artículo 286 del Código de Justicia Militar.

A propósito de esta figura de exclusiva competencia del fuero castrense, interesante resulta el análisis de Renato Astrosa, quien sostiene que en caso de provocar el sujeto pasivo las ofensas, no se incurre en desacato, sino en el delito común de injurias, por cuanto la víctima con su actitud se ha despojado de su investidura militar. ${ }^{31}$

En cuanto al verbo rector del Artículo 283 del Código de Justicia Militar la voz "ofender", a juicio de Astrosa ${ }^{32}$ no sólo es injuriar, sino también denostar, fastidiar o enfadar, siendo por lo tanto un concepto en cierto sentido más amplio que el de injuriar, definido por la Ley común como "toda expresión proferida o acción ejecutada en deshonra, descrédito o menosprecio de otra persona". 33

la amenaza, lo cual podría llevar a interpretaciones amplias que permitirían que las acciones anteriormente consideradas como desacato sean penalizadas indebidamente a través del tipo penal de amenazas.

${ }^{27}$ El Artículo 416 del Código Penal define injuria como toda expresión proferida o acción ejecutada en deshonra, descrédito o menosprecio de otra persona.

${ }^{28}$ El Artículo 426 del Código de Justicia Militar sostiene que la palabra "Ejército" empleada en los Libros I, II y III de este Código, comprenderá asimismo a la Armada, Fuerza Aérea y Carabineros y la palabra "militar" a los miembros de aquellas instituciones.

29 Artículo 283 del Código de Justicia Militar: El que amenazare u ofendiere con palabras o gestos a centinela, guarda o fuerza armada, será castigado con la pena de prisión en su grado máximo a reclusión menor en su grado mínimo.

Pero si el hecho se efectuare en campaña, la pena se elevará en uno o dos grados.

30 Artículo 285 del Código de Justicia Militar: para los efectos de los artículos 281 a 283, se considerará como centinela al encargado del servicio telegráfico o telefónico militar mientras esté en funciones, al que haga el servicio de imaginaria dentro del cuartel y, en general, a todos aquellos a quienes los reglamentos del Ejército denominen centinelas o guardas; y se considerará fuerza armada a toda pareja encargada de la conducción de pliegos u órdenes.

Artículo 423 del Código de Justicia Militar: Se considera fuerza armada a los individuos del Ejército reunidos de acuerdo con los reglamentos, para el desempeño de cualquier acto del servicio o para la ejecución de cualquiera función táctica.

31 Astrosa, R, Derecho Penal Militar, $2^{a}$ ed., Ed. Jurídica de Chile, Santiago, 1974. pp. 261 y ss, donde agrega que la jurisprudencia de los tribunales españoles ha recogido, en reiteradas ocasiones, esta teorí; pero también ha exonerado de responsabilidad al reo fundándose en la existencia, en esos casos, de una causal de justificación: "Las formas provocadoras o improcedentes usadas por el centinela, salvaguardia o fuerza armada, al dirigirse a determinadas personas, pueden llegar a justificar las expresiones verbales injuriosas de éstas que se profieran como retorsión y sean motivadas por el natural acaloro" (Sentencia del Consejo Supremo de 24 de junio de 1892).

32 Astrosa, R, Derecho Penal Militar, 2a ed., Ed. Jurídica de Chile, Santiago, 1974. p. 262.

33 Artículo 416 del Código Penal. 
Agrega este autor que la expresión ofender es en cierto sentido más amplia que la de injuriar, por cuanto en materia militar toda acción ejecutada en deshonra, descrédito o menosprecio de otra persona, esto es, lo que se llama injuria de hecho o de obra, importa siempre un delito de violencia o de maltrato y no un delito de ofensas, por cuanto la Ley penal militar, a diferencia de la ley ordinaria que emplea en los delitos contra el honor los verbos injuriar y calumniar o difamar, usa permanentemente el verbo ofender, con excepción del Artículo 284 del Código de Justicia Militar que emplea, además, el verbo injuriar. ${ }^{34}$

En ese sentido advertimos desde ya que el delito de desacato del Artículo 283 del catálogo de delitos militares no sólo pugna con la garantía que reconoce a la libertad de expresión como un límite al ejercicio de la soberanía, sino que del mismo se realizan interpretaciones que infringen abiertamente el principio de igualdad ante la ley, desde que se pretende extender el ámbito de aplicación del injusto, atribuyéndole al verbo ofender un significado que va más allá de su sentido natural, al pretender caprichosamente extenderlo hasta el punto de abarcar las acciones que causan mero fastidio a la víctima, con la única pretensión de conferirle al militar un resguardo penal más intenso que el ofrecido a las más altas autoridades del Estado y al resto de la población.

En tanto, el Artículo 284 del Código de Justicia Militar castiga con pena de presidio menor en su grado mínimo a medio al que ofendiere o injuriare de palabra o por escrito o por cualquier otro medio a las Fuerzas Armadas, ${ }^{35}$ sus unidades, reparticiones, armas, clases o cuerpos determinados, o a uno de sus integrantes con conocimiento de su calidad de miembro de esas instituciones.

Por lo tanto, la descripción de este tipo penal del Artículo 284 del Código de Justicia Militar abraza dos figuras distintas, el delito común de desacato a las Fuerzas Armadas cometido por civiles, de conocimiento de la justicia ordinaria, y el delito propiamente militar derivado de la realización culpable por parte de un uniformado de esa misma acción injuriosa.

Así, por lo demás, lo reconoce expresamente el legislador que entiende por delitos militares sólo aquéllos expresamente tipificados en el código de la especialidad, ${ }^{36}$ con excepción de las figuras descritas en los artículos 284 y 417 del mismo texto, siempre y cuando hubieren sido cometidos por civiles en cuyo caso serán juzgados por los tribunales ordinarios con competencia penal, como por ejemplo los juzgados de garantía.

Como sea, esta forma de desacato a las Fuerzas Armadas y sus integrantes en general fue perseguida por la justicia militar, especialmente cuando los imputados eran civiles

${ }^{34}$ Astrosa, R, óp. cit, p. 262.

${ }^{35}$ El Artículo 101 de la Constitución Política del Estado dispone que las Fuerzas Armadas dependientes del Ministerio encargado de la Defensa Nacional están constituidas única y exclusivamente por el Ejército, la Armada y la Fuerza Aérea.

${ }^{36}$ Artículo $5^{\circ}$ del Código de Justicia Militar: Corresponde a la jurisdicción militar el conocimiento:

1. ${ }^{\circ}$ De las causas por delitos militares, entendiéndose por tales los contemplados en este Código, excepto aquellos a que dieren lugar los delitos cometidos por civiles previstos en los artículos 284 y 417 , cuyo conocimiento corresponderá en todo caso a la justicia ordinaria, y también de las causas que leyes especiales sometan al conocimiento de los tribunales militares. 
y sus dichos propalados por medios de comunicación social, lo que como sabemos fue uno de los antecedentes tenidos en consideración por las denominadas Leyes Cumplido para confiar a partir de 1991 a la justicia ordinaria este tipo de asuntos.

Por ejemplo, en la causa 455-87 proveniente del Segundo Juzgado Militar el Ministerio Público Castrense recurrió de queja en contra de la resolución que en segunda instancia revocó la condena impuesta al abogado especialista en derechos humanos Roberto Garretón, como autor del delito de ofensas a las Fuerzas Armadas, acusación originada a propósito de la circulación de la edición N $^{\circ} 357$ de marzo de 1987 de la Revista Mensaje, donde se publicó un artículo suscrito por el referido profesional y que fue estimado como lesivo de la dignidad y prestigio de las Fuerzas Armadas. ${ }^{37}$

En tanto, sólo un recurso de casación en el fondo interpuesto ante la Excma Corte Suprema pudo revertir la condena de 541 días de presidio menor en su grado medio impuesta por el Cuarto Juzgado del Crimen de Santiago al periodista Gilberto Palacios Escobedo y al entonces director del semanario Fortín Mapocho, Luis Pozo Ruiz, luego que ese periódico publicara en su edición No 357 de 14 de abril de 1986 un artículo titulado

${ }^{37}$ Portal Electrónico Lexis Nexis, Número Identificador: 11481. Recurso de Queja Rechazado por la Corte Suprema el 16 de septiembre de 1991 en causa caratulada Fiscalía Militar con Roberto Garretón Merino:

Sentencia:

Informe Corte de Apelaciones Excma. Corte Suprema: Luis Correa Bulo y María Antonia Morales Villagrán, Ministros de la Segunda Sala de la Corte Marcial, informando al tenor del recurso de queja Rol No 1.037 interpuesto por don Enrique Ibarra Chamorro, en su calidad de Fiscal General Militar Interino, respetuosamente exponemos: Se ha recurrido de queja en contra nuestra porque en el proceso $\mathrm{N}^{\circ}$ 455-87 del Segundo Juzgado Militar (Cuarta Fiscalía), por sentencia de veinticinco de octubre último, acordada en empate de votos, revocamos la de primera instancia que condenó al abogado don Roberto Garretón Merino, como autor del delito de ofensas a las Fuerzas Armadas, absolviéndolo del cargo formulado en su contra. Los fundamentos que tuvimos para proceder del modo que se nos reprocha y que en concepto del Ministerio Público Militar importaría falta o abuso, se encuentran contenidos en nuestra sentencia cuyos considerandos pertinentes transcribimos a continuación: Que la presente causa ha sido incoada en razón de la publicación efectuada en la Revista Mensaje, correspondiente al No 357 de marzo a abril de 1987, sobre la situación de los derechos humanos, la que contendría expresiones ofensivas e injuriosas a las Fuerzas Armadas y en especial al Servicio de Justicia Militar, afectando su prestigio, dignidad y organización. Que la publicación corresponde a un estudio sobre los derechos humanos en Chile, en 1986, que al decir de los querellados (declaraciones de fs. 14 y 15), fue encargado por el abogado Garretón a la señorita María Allende, en base al informe anual sobre esta materia elaborado por la Vicaría de la Solidaridad, trabajo que confeccionado por la señorita Allende fue corregido por el encausado y publicado en la Revista Mensaje. Que la publicación aludida si bien se contienen expresiones duras, ella no refleja el propósito de ofender deliberadamente a las Fuerzas Armadas o a sus integrantes, sino se limita dicha publicación a efectuar un estudio analítico y crítico respecto de hechos en que se ha inculpado a funcionarios militares, algunos de los cuales están conociendo los Tribunales de Justicia. Que es prohibido a los jueces imponer condena alguna cuando no han adquirido la convicción de haberse perpetrado realmente un delito y que en él ha correspondido una participación culpable al acusado. Es cuanto podemos informar a US. Excma. Dios guarde a US. Excma. Luis Correa Bulo, Ministro; María Antonia Morales Villagrán, Ministro. Al señor Presidente de la Excma. Corte Suprema. CORTE SUPREMA Santiago, 16 de septiembre de 1991. Vistos: Con lo informado por los Ministros recurridos, antecedentes traídos a la vista y por no existir falta ni abuso susceptible de enmendarse por esta vía, se declara sin lugar el recurso de queja deducido en lo principal de fs. 1. Proveído por la Excma. Corte Suprema, Presidente señor Cereceda, Ministros señores Béraud y Carrasco y Abogados Integrantes señores Infante y Fernández. Rol N ${ }^{\circ} 1.037$ 
Juicio al Servicio Militar, donde se vertieron expresiones, juicios y conceptos relativos al cumplimiento de la obligación constitucional del servicio militar, las que, en definitiva, el tribunal consideró ofendían gravemente el prestigio y honor de las Fuerzas Armadas en general y del Ejército en particular. ${ }^{38}$

Conociendo de la impugnación a la sentencia condenatoria, la Excma Corte Suprema coincidió con los recurrentes al considerar que no se vulneró el Artículo 284 del Código de Justicia Militar, pues las imputaciones que se hacen en el citado reportaje corresponden al desarrollo y análisis de una crónica, en la que se equilibra una crítica adversa al Servicio Militar con otros juicios de carácter positivo al mismo y las expresiones que se estiman como ofensivas o injuriosas se enmarcan dentro de juicios críticos a una situación determinada. 39

Sin embargo, la decisión estuvo lejos de ser unánime y de hecho los ministros titulares de la sala, señores Roberto Dávila y Adolfo Bañados, ${ }^{40}$ estuvieron por confirmar la pena, al estimar que ningún error de derecho se cometió por parte del tribunal de la instancia al calificar como constitutivas de ofensas a las Fuerzas Armadas y al Ejército las expresiones contenidas en la referida publicación.

Si bien los casos citados corresponden a episodios desencadenados al término de la dictadura militar, la experiencia demuestra que los tipos penales vigentes en nuestro ordenamiento jurídico pueden perfectamente invocarse a efectos de justificar la persecución penal pública, como de hecho ocurriría, por ejemplo, si frente a eventuales expresiones o críticas que pudieran surgir al interior del debate democrático, las Fuerzas Armadas o sus miembros pudieran estimar ofendido su honor o prestigio y configurado alguno de los delitos de desacato que a nuestro juicio ilegítimamente subsisten en el Código de Justicia Militar.

\section{3. ¿SON DELITOS MILITARES?}

Es probable que exista disidencia frente a las opiniones que postulan la inconstitucionalidad de los artículos 283 y 284 del Código de Justicia Militar, sobre la base de

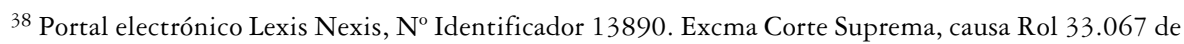
23 de mayo de 1996 recaída en recursos de casación en la forma y en el fondo sobre materia criminal.

39 Ibíd, cita $\mathrm{N}^{\circ}$ 40. El considerando $7^{\circ}$ del fallo sostiene: Que, por otra parte, no resulta suficiente para configurar el delito de que se trata ni asignar responsabilidades al autor ni al director del medio de comunicación, la sola circunstancia de algunos conceptos vertidos en el reportaje, pues se precisa, además, una voluntad dolosa por parte del agente y de los antecedentes de autos no aparece justificada la existencia del animus injuriando sino que, básicamente un ánimo de narrar hechos y analizarlos, situación que queda fuera de la carta del delito que se imputa a los acusados.

${ }^{40}$ Se sostiene que la mayoría de los ministros titulares de la sala estuvieron por confirmar la condena impuesta a ambos periodistas como autores de desacato del Artículo 284 del Código de Justicia Militar, desde que sólo el ministro Guillermo Navas estuvo por acoger el recurso y si, en definitiva, la casación de fondo prosperó fue gracias a los votos de los abogados integrantes de la sala, señores Mario Verdugo y Emilio Pfeffer, quienes fueron determinantes en la conformación de la mayoría que anuló la condena y absolvió a los recurrentes. 
estimar que el bien jurídico protegido por ambas normas no es el honor de las Fuerzas Armadas y sus miembros, sino uno estricta y exclusivamente castrense como el orden y seguridad de estas instituciones, cuestión que explicaría su omisión de las leyes y proyectos que derogaron figuras análogas de la Ley de Seguridad Interior del Estado y de nuestro Código Penal.

A efectos de controvertir esta argumentación, hacemos nuestros los argumentos del profesor Jorge Mera, quien sostiene que en la doctrina actual existe un amplio consenso en el sentido de calificar de especial al delito militar, a partir de los dos elementos copulativos que lo integran, caracterizan y distinguen de los delitos comunes: la naturaleza militar del bien jurídico y la calidad del autor que infringe sus deberes militares, esto es, los que le corresponden en tanto miembros de las Fuerzas Armadas. ${ }^{41}$

En consecuencia, el concepto de delito militar utilizado por el Artículo $5^{\circ}$ del Código de Justicia Militar aparece francamente reñido con las definiciones doctrinarias y dogmáticas manejadas por el pensamiento democrático contemporáneo. Y en ese sentido, destacamos que el carácter especial de este tipo de delitos no es, ni puede ser la investidura castrense del autor, sino fundamentalmente la naturaleza militar del bien jurídico merecedor de la tutela jurídico-penal, como por ejemplo la seguridad externa del Estado o su capacidad de defensa. ${ }^{42}$

Así, el profesor Jorge Mera sostiene que la identificación del bien jurídico protegido en esta clase especial de infracciones debe hacerse a partir de la función que le corresponde a las Fuerzas Armadas como entidades técnicas especializadas en la defensa de la seguridad exterior del Estado y, por eso, se afirma que en un sentido amplio y genérico, el bien jurídico protegido en estos delitos es la seguridad exterior del Estado. ${ }^{43}$

Sin embargo, los fines de certeza y seguridad jurídica asignados a los tipos de injusto militar no parecen suficientemente garantizados cuando se pretende caracterizar bajo el rótulo de seguridad exterior del Estado el bien jurídico protegido por los llamados delitos castrenses, desde que, por ejemplo, tanto el Código Penal como la Ley de Seguridad Interior del Estado contemplan figuras orientadas a su tutela.

En estricto rigor, un genuino catálogo de especiales delitos militares debiera construirse con el propósito de resguardar la seguridad exterior del Estado frente a una específica y determinada creación de peligro o lesión derivada de la guerra, porque tal como lo sostiene el tratadista Raúl Eugenio Zaffaroni ${ }^{44}$ la ratio essendi del derecho penal militar ordinario es la necesidad de erigir y sostener un cuerpo técnico, que en tiempo de

${ }^{41}$ Mera, J., "La Parte Especial del Derecho Penal Militar Chileno", en Mera Figueroa, J. (Editor), Hacia una Reforma de la Justicia Militar, Cuadernos de Análisis Jurídico de la Universidad Diego Portales, Santiago, octubre, 2002, p. 13.

42 Rodríguez, A., "Delitos militares y jurisdicción militar", en Mera Figueroa, J. (Editor), Justicia militar y estado de derecho, Cuadernos de Análisis Jurídico de la Universidad Diego Portales, Santiago, 1998, p. 232.

${ }^{43}$ Mera, J., "La Parte Especial del Derecho Penal Militar Chileno", en Mera Figueroa, J. (Editor), Hacia una Reforma de la Justicia Militar, Cuadernos de Análisis Jurídico de la Universidad Diego Portales, Santiago, octubre, 2002, p. 14.

${ }^{44}$ Zaffaroni, R. y Cavallero, R., "Derecho Penal Militar", Ariel, Buenos Aires, 1980, pp. 46 y 47. 
paz tiene carácter preventivo, frente a la amenaza de una situación de necesidad enorme -la guerra- y en tiempo de guerra asume el carácter defensivo frente a la actualización de esa necesidad.

En consecuencia, una conducta militar formalmente antijurídica ${ }^{45}$ y que realiza la descripción típica al desobedecer los deberes impuestos por el uniforme, no necesariamente estremece el bien jurídico protegido por el derecho penal castrense, ni autoriza la imposición de una pena, ni es óbice a la procedencia del correspondiente reproche disciplinario.

Dicho de otro modo, no basta una infracción a los deberes militares para que exista delito. Como requisito copulativo es necesario además que se afecte realmente la eficacia de las instituciones armadas en el evento de una guerra, porque de lo contrario, la infracción del deber militar - por no afectar un bien jurídico vital, universal, sino que sólo intereses institucionales de carácter castrense- debe quedar dentro del ámbito de la responsabilidad disciplinaria. ${ }^{46}$

Respecto del sujeto activo, la doctrina no vacila a la hora de calificar de especiales tales delitos en razón de la calidad militar del autor, porque como sostienen Zaffaroni y Cavallero, el delito militar ha menester copulativamente tanto de la calidad del autor como del carácter castrense que debe investir, porque si el delito militar entraña una violación al deber militar, no nos parece dudoso que la Ley militar sólo pueda dirigir su mandato, y exigir su cumplimiento a quien ostente ese carácter. ${ }^{47}$

\section{3.a. Innecesaria preservación de los artículos 283 y 284 en el Código de Justicia Militar}

Si se vuelve a revisar el contenido de los delitos de desacato injurias, descritos en el Código de Justicia Militar, se advierte que se trata de delitos comunes. El Artículo 283 castiga al que ofendiere con palabras o gestos a centinela, guarda o fuerza armada y la norma siguiente a quien ofendiere o injuriare de palabra o por escrito o por cualquier otro medio a las Fuerzas Armadas, sus unidades, reparticiones, armas, clases o cuerpos

45 Politoff, S., "Derecho Penal", Tomo I, Ed. Jurídica Conosur, $2^{a}$ Ed., Santiago, 2001, p. 256. El concepto de antijuridicidad formal representa la relación de contradicción de la conducta con los mandatos y prohibiciones del orden jurídico, en cambio el concepto de antijuridicidad material concierne a la lesión o puesta en peligro de bienes jurídicos, esto es, a su dañosidad social. En el llamado "fallo del veterinario", el Tribunal Supremo de los Países Bajos absolvió al veterinario que facultado para vacunar ganado contra la fiebre aftosa optó por poner en contacto vacas que no daban leche con ganado infectado. Con ello se obtendría el mismo resultado que con la vacuna, ya que los animales se enfermarían ligeramente en el período en que no son ordeñadas. La Ley sobre ganadería prohibía, sin embargo, el hecho de colocar intencionalmente en contacto ganado sano con animales infectados con fiebre aftosa. El tipo legal existía y ninguna causa de justificación formalmente prevista en la Ley holandesa podía ser aplicada, pese a lo cual el tribunal juzgó que el hecho carecía de antijuridicidad, es decir, que, aunque la conducta podía subsumirse en la descripción legal, faltaba la materialidad del daño o peligro que servía de fundamento a la prohibición.

${ }^{46}$ Mera, J., "La Parte Especial del Derecho Penal Militar Chileno", en Mera Figueroa, J. (Editor), Hacia una Reforma de la Justicia Militar, Cuadernos de Análisis Jurídico de la Universidad Diego Portales, Santiago, octubre, 2002, p. 15.

${ }^{47}$ Zaffaroni, R. y Cavallero, R., "Derecho Penal Militar", Ariel, Buenos Aires, 1980, p. 200. 
determinados, o a uno de sus integrantes, con conocimiento de su calidad de miembro de esas instituciones.

Desde luego, ambos tipos penales no requieren calidades de ninguna especie en el sujeto activo del delito, salvo las propias de la imputabilidad, y, por lo mismo, en virtud de esa razón no pueden ser considerados sino delitos comunes. Y, a mayor abundamiento, en el caso de ser civiles los autores de las conductas descritas en el Artículo 284 del CJM, ellas serán entregadas al conocimiento y fallo de la justicia ordinaria y las del Artículo 283 del mismo texto que fueren atribuibles a los particulares quedan sujetas a la denominada impropia competencia de la jurisdicción militar, cuestión que viene a refrendar su carácter de delito común.

Sólo en aquellos casos en que estas formas de desacato son cometidas por militares, podría discutirse si ellas importan una infracción a los deberes militares y, en consecuencia, son disciplinariamente reprochables o si, además, crean también un inaceptable peligro sobre el funcionamiento que la fuerza militar requiere para cautelar debidamente la seguridad exterior del Estado frente a una situación de guerra.

De hecho, el profesor Jorge Mera se inclina decididamente por eliminar del Código de Justicia Militar estos delitos a los que estima innecesarios, desde que el propio texto marcial considera como una circunstancia agravante ser el culpable militar, además de estar sancionado con penas ordinarias como el presidio y la prisión. ${ }^{48}$

Asegura que manifiestamente no se trata de delitos militares, toda vez que no se infringe deber militar alguno y esto resulta evidente en caso de ser el sujeto activo un civil, agregando que si el delito lo comete un militar, el hecho, en su caso, dará lugar a los delitos castrenses de infracción de los deberes tanto de superiores como subordinados.

De alguna manera, el propio Código de Justicia Militar reconoce que las injurias y ofensas proferidas por uniformados en estricto rigor no corresponden a delitos materialmente castrenses, sino que su carácter especial es meramente formal, tal como se desprende del Artículo 206 de dicho texto que dispone que la injuria y la calumnia entre militares se considerará siempre delito militar, pero se penará de acuerdo con la Ley común, salvo que constituya un delito especialmente penado por este Código.

De no existir esta disposición, la injuria o calumnia proferida en contra de un inferior o entre militares que no tienen relación jerárquica serían de conocimiento de la justicia ordinaria. Y sólo en razón de la ficción legal de considerarlos como delitos militares, conocen de ellos los tribunales militares. ${ }^{49}$

Incluso a nivel comparado hay autores que incluyen a los delitos de desacato e injurias a la autoridad entre aquellos irreprochables en atención al principio de insignificancia, como un verdadero elemento negativo del tipo, argumentando que, por ejemplo, en

${ }^{48}$ Mera, J., "La Parte Especial del Derecho Penal Militar Chileno", en Mera Figueroa, J. (Editor), Hacia una Reforma de la Justicia Militar, Cuadernos de Análisis Jurídico de la Universidad Diego Portales, Santiago, octubre, 2002, p. 29.

49 Mera, J., "Bases programáticas para la reforma integral del derecho penal militar chileno", Informe de Investigación $\mathrm{N}^{\circ}$ 16, Centro de Investigaciones Jurídicas, Facultad de Derecho de la Universidad Diego Portales, Santiago, 2003, pp. 18-19. 
los casos de faltas de respeto a la autoridad se advierte un mínimo desvalor objetivo del acto y que otras formas de desacato dejaron de ser constitutivas de delito en el Código Penal español de 1995. ${ }^{50}$

\section{La doble tensión Sobre las garantías del Estado de Derecho}

Hasta el día de hoy el civil que ofendiere con palabras o con gestos a centinela, guarda o fuerza armada comete un delito que, de modo ficto, ha sido considerado por nuestra legislación como militar, aunque no se afecte un bien jurídico de esa especie, ni se realice por un agente uniformado.

En consecuencia, en las hipótesis del Artículo 283 del Código de Justicia Militar la decisión sobre la inocencia o culpabilidad del imputado y la determinación de la pena, en su caso, serán de competencia de un juez militar, no letrado, que no goza de inamovilidad en el cargo y, por el contrario, que continúa como funcionario de servicio activo del cuerpo armado a cuyas filas pertenece, subordinado desde el punto de vista administrativo a la jerarquía de las autoridades de la institución, con lo cual no puede gozar de la independencia mínima necesaria para ejercer jurisdicción -como lo había señalado públicamente el Presidente de la Corte Suprema, en el discurso de inauguración del año judicial de 1989. ${ }^{51}$

Distinta es la situación del Artículo 284 del Código de Justicia Militar, porque si bien en febrero de 1991 la Ley 19.047 - una de las Leyes Cumplido- excluyó de la competencia de los Tribunales Militares a los civiles que cometieran injurias a las Fuerzas Armadas o a sus miembros, dejó incólume la amenaza penal para este tipo de conductas y preservó la facultad estatal de perseguirlas de oficio, privilegio que hoy nuestra legislación no reconoce a ninguna autoridad, ni siquiera al Presidente de la República, ni tampoco a Carabineros, desde que el año 2005 se derogó esta especie de desacato. ${ }^{52}$

Por lo tanto, el Código de Justicia Militar preserva una doble tensión sobre las garantías del Estado de Derecho democrático, porque en materia de desacato mantiene el Artículo 283 que somete a los imputados civiles a las reglas de un procedimiento inquisitivo que, entre sus múltiples defectos autoritarios, restringe severamente el derecho a defensa técnica de calidad e ilegítimamente preserva el Artículo 284 que, al

${ }^{50}$ Luzón Peña, D. M., "Curso de Derecho Penal", Tomo I, primera reimpresión, Ed. Universitas, Madrid, 1999 , p. 566.

${ }^{51}$ Luis Maldonado, Presidente de la Corte Suprema, en su Discurso de inauguración del año judicial de 1989, citado por Couso, J., "Competencia de la justicia militar. Una perspectiva político-criminal", en Mera, Jorge (Editor), Hacia una Reforma de la Justicia Militar, Cuadernos de Análisis Jurídico, Escuela de Derecho de la Universidad Diego Portales, Santiago, 2002, p. 73, nota 3.

52 El 31 de agosto y 29 de septiembre del año 2005 se publicaron también las leyes 20.048 y 20.064, la primera de las cuales derogó la figura de desacato en su modalidad de injurias y calumnias del Código Penal y la segunda ajustó a esos términos el Artículo 417 del Código de Justicia Militar que castigaba penalmente al que ofendiere o injuriare de palabra o por escrito o por cualquier otro medio a funcionarios de Carabineros e Investigaciones. 
igual que el anterior, coarta la libertad de expresión al calificar de desacato la crítica acerba a las Fuerzas Armadas o a sus miembros.

\section{4.a. Debido proceso y justicia militar}

Antes de referirnos a los cuestionamientos de fondo formulados a las figuras de desacato-injurias a la autoridad, en forma previa es necesario pronunciarse sobre las escasas y a veces nulas garantías reconocidas a los imputados civiles que, por este tipo de hechos, deberán comparecer ante las instancias de la hermética justicia militar, como de hecho ocurriría en caso de ofender un particular con palabras o gestos a centinela, guarda o fuerza armada.

La recta doctrina ha dicho que es una exigencia del derecho internacional que, tanto en tiempos de paz como en estados de emergencia, todo tribunal militar con competencia en materia penal sobre personas civiles respete las garantías judiciales que dan contenido al debido proceso ${ }^{53}$.

53 Convención Americana sobre Derechos Humanos. Art. 8: Garantías Judiciales 1. Toda persona tiene derecho a ser oída, con las debidas garantías y dentro de un plazo razonable, por un juez o tribunal competente, independiente e imparcial, establecido con anterioridad por la ley, en la sustanciación de cualquier acusación penal formulada contra ella o para la determinación de sus derechos y obligaciones de orden civil, laboral, fiscal o de cualquier otro carácter. 2. Toda persona inculpada de delito tiene derecho a que se presuma su inocencia mientras no se establezca legalmente su culpabilidad. Durante el proceso, toda persona tiene derecho en plena igualdad a las siguientes garantías mínimas: a) derecho del inculpado de ser asistido gratuitamente por el traductor o intérprete, si no comprende o no habla el idioma del juzgado o tribunal; b) comunicación previa y detallada al inculpado de la acusación formulada; c) concesión al inculpado del tiempo y de los medios adecuados para la preparación de su defensa; d) derecho del inculpado de defenderse personalmente o de ser asistido por un defensor de su elección y de comunicarse libre y privadamente con su defensor; e) derecho irrenunciable de ser asistido por un defensor proporcionado por el Estado, remunerado o no según la legislación interna si el inculpado no se defendiere por sí mismo ni nombrare defensor dentro del plazo establecido por la ley; f) derecho de la defensa de interrogar a los testigos presentes en el tribunal y de obtener la comparecencia, como testigos o peritos, de otras personas que puedan arrojar luz sobre los hechos; g) derecho a no ser obligado a declarar contra sí mismo ni a declararse culpable, y h) derecho de recurrir del fallo ante juez o tribunal superior. 3. La confesión del inculpado solamente es válida si es hecha sin coacción de ninguna naturaleza. 4. El inculpado absuelto por una sentencia firme no podrá ser sometido a nuevo juicio por los mismos hechos. 5. El proceso penal debe ser público, salvo en lo que sea necesario para preservar los intereses de la justicia.

Artículo 14 del Pacto Internacional de Derechos Civiles y Políticos:

1. Todas las personas son iguales ante los tribunales y cortes de justicia. Toda persona tendrá derecho a ser oída públicamente y con las debidas garantías por un tribunal competente, independiente e imparcial, establecido por la ley, en la substanciación de cualquier acusación de carácter penal formulada contra ella o para la determinación de sus derechos u obligaciones de carácter civil. La prensa y el público podrán ser excluidos de la totalidad o parte de los juicios por consideraciones de moral, orden público o seguridad nacional en una sociedad democrática, o cuando lo exija el interés de la vida privada de las partes o, en la medida estrictamente necesaria en opinión del tribunal, cuando por circunstancias especiales del asunto la publicidad pudiera perjudicar a los intereses de la justicia; pero toda sentencia en materia penal o contenciosa será pública, excepto en los casos en que el interés de menores de edad exija lo contrario, o en las acusaciones referentes a pleitos matrimoniales o a la tutela de menores. 
Autores como el profesor de derecho penal y procesal penal de la Universidad de Buenos Aires Alberto Bovino sostienen que la experiencia de nuestra región permite afirmar que, como regla, la intervención de tribunales militares en el juzgamiento de civiles implica una práctica sistemática de violaciones a los derechos humanos que los Estados tienen el deber de respetar conforme a las obligaciones jurídicas establecidas por el derecho internacional. ${ }^{54}$

Y en ese sentido, la mayor y más frecuente vulneración de las garantías del debido proceso cometidas por la administración de justicia militar en el juzgamiento de civiles deriva de su falta de independencia e imparcialidad, originada no sólo en el hecho de perseguir a sus propios enemigos, sino también fruto de su estructura orgánica.

Por ejemplo, la Comisión Interamericana de Derechos Humanos, analizando la integración de los tribunales militares chilenos, señaló:

El titular de la jurisdicción militar es un oficial militar en servicio activo, subordinado jerárquicamente a sus autoridades y carente, por tanto, de la independencia

2. Toda persona acusada de un delito tiene derecho a que se presuma su inocencia mientras no se pruebe su culpabilidad conforme a la ley.

3. Durante el proceso, toda persona acusada de un delito tendrá derecho, en plena igualdad, a las siguientes garantías mínimas:

a) A ser informada sin demora, en un idioma que comprenda y en forma detallada, de la naturaleza y causas de la acusación formulada contra ella;

b) A disponer del tiempo y de los medios adecuados para la preparación de su defensa y a comunicarse con un defensor de su elección;

c) A ser juzgado sin dilaciones indebidas;

d) A hallarse presente en el proceso y a defenderse personalmente o ser asistida por un defensor de su elección; a ser informada, si no tuviera defensor, del derecho que le asiste a tenerlo, y, siempre que el interés de la justicia lo exija, a que se le nombre defensor de oficio, gratuitamente, si careciere de medios suficientes para pagarlo;

e) A interrogar o hacer interrogar a los testigos de cargo y a obtener la comparecencia de los testigos de descargo y que éstos sean interrogados en las mismas condiciones que los testigos de cargo;

f) A ser asistida gratuitamente por un intérprete, si no comprende o no habla el idioma empleado en el tribunal;

g) A no ser obligada a declarar contra sí misma ni a confesarse culpable.

4. En el procedimiento aplicable a los menores de edad a efectos penales se tendrá en cuenta esta circunstancia y la importancia de estimular su readaptación social.

5. Toda persona declarada culpable de un delito tendrá derecho a que el fallo condenatorio y la pena que se le haya impuesto sean sometidos a un tribunal superior, conforme a lo prescrito por la ley.

6. Cuando una sentencia condenatoria firme haya sido ulteriormente revocada, o el condenado haya sido indultado por haberse producido o descubierto un hecho plenamente probatorio de la comisión de un error judicial, la persona que haya sufrido una pena como resultado de tal sentencia deberá ser indemnizada, conforme a la ley, a menos que se demuestre que le es imputable en todo o en parte el no haberse revelado oportunamente el hecho desconocido.

7. Nadie podrá ser juzgado ni sancionado por un delito por el cual haya sido ya condenado o absuelto por una sentencia firme de acuerdo con la Ley y el procedimiento penal de cada país.

${ }^{54}$ Bovino, A., "La justicia militar y juzgamiento de civiles", en Mera, Jorge (Editor), Justicia Militar y Estado de Derecho, Cuadernos de Análisis Jurídico, Escuela de Derecho de la Universidad Diego Portales, Santiago, 1998, p. 301. 
funcional imprescindible...En su calidad de oficial en servicio activo carece también de inamovilidad y, adicionalmente y por razones de su profesión, este oficial no posee la formación jurídica que es exigible a un juez... La inamovilidad de los jueces y su adecuada preparación profesional son requisitos que tienden a asegurar esa independencia y el correcto cumplimiento de las delicadas funciones que les son encomendadas. ${ }^{55}$

Se ha dicho, por ejemplo, que la jurisdicción castrense vulnera la garantía de la igualdad ante la ley, desde que no asegura debidamente a los imputados civiles independencia e imparcialidad en el juzgamiento, por cuanto sus decisiones son emitidas por uniformados, no sólo inclinados naturalmente a identificarse con los intereses de los institutos armados, sino además impedidos de sustraerse de las expectativas y eventuales presiones de sus superiores, también militares en servicio. ${ }^{56}$

Y de esa falta de independencia del servicio de justicia militar se derivan los cuestionamientos a propósito de su parcialidad en la adopción de las decisiones y afectación de otras garantías del debido proceso, entre las que se pueden mencionar: concentración desmesurada de las facultades de investigar, acusar y sentenciar; desconocimiento de la presunción de inocencia; predominio de la detención y la prisión preventiva como medidas cautelares personales; restricciones injustificadas para acceder a un abogado de confianza; inexistencia del derecho a contar con un defensor técnico idóneo, proporcionado por el Estado; carácter secreto del procedimiento; delegación de funciones jurisdiccionales en empleados administrativos y todos aquellos vicios que nos recuerdan a nuestra antigua justicia del crimen, vigente hasta antes de la aplicación de la reforma procesal penal.

Estas falencias no han sido corregidas y así lo confirma la sentencia de la Corte Interamericana de Derechos Humanos de noviembre de 2005 que en su condena al Estado de Chile sostuvo que al asumir el conocimiento de la causa $\mathrm{N}^{\circ} 471$ por el delito de desacato, las autoridades del Juzgado Naval de Magallanes procesaron al señor Palamara Iribarne por haber injuriado u ofendido a la Fiscalía Naval, por lo que las autoridades a cargo de este proceso, todas ellas integrantes de las Fuerzas Armadas, debían pronunciarse sobre un asunto en el que el interés de las mismas se veía afectado, por lo cual la imparcialidad e independencia del tribunal era cuestionable. ${ }^{57}$

Además de los problemas que surgen de la amplitud de la competencia de la jurisdicción penal militar en Chile para juzgar civiles, de la falta de imparcialidad

55 Comisión Interamericana de Derechos Humanos, Informe Chile (1985), p.199, citado por Bovino, A., "La justicia militar y juzgamiento de civiles", en Mera, Jorge (Editor), Justicia Militar y Estado de Derecho, Cuadernos de Análisis Jurídico, Escuela de Derecho de la Universidad Diego Portales, Santiago, 1998, p. 303, nota 51 .

${ }^{56}$ Couso, J., "Competencia de la justicia militar. Una perspectiva político-criminal", en Mera, Jorge (Editor), Hacia una Reforma de la Justicia Militar, Cuadernos de Análisis Jurídico, Escuela de Derecho de la Universidad Diego Portales, Santiago, 2002, p. 78.

57 Corte Interamericana de Derechos Humanos. Caso Palamara Iribarne vs Chile, sentencia de 22 de noviembre de 2005, reproducida por Nogueira Alcalá, Humberto, "El debido proceso en la Constitución y el sistema interamericano", Ed. Librotecnia, Santiago, 2007, pp. 464-465. 
e independencia de sus tribunales, propia de su estructura y composición, la Corte Interamericana considera que la normativa que confiere el carácter de secreto al sumario del procedimiento penal militar es contraria al derecho a defensa del imputado, ya que le imposibilita el acceso efectivo al expediente y a las pruebas que se recaban en su contra, lo cual le impide defenderse adecuadamente, en contravención de lo dispuesto en el Artículo 8.2.c) de la Convención Americana de Derechos Humanos. ${ }^{58}$

Agrega el mismo tribunal internacional que debido a que en la etapa de sumario el defensor no puede estar presente en la declaración del imputado y, como ha sucedido en este caso, tuvo que solicitar diligencias probatorias al fiscal sin tener conocimiento del sumario ni del fundamento de los cargos formulados a su defendido, el derecho del imputado a ser asistido por un defensor consagrado en el Artículo 8.2.d) de la Convención también se vio afectado. ${ }^{59}$

Coincidimos con Regina Díaz Tolosa cuando afirma que el Estado de Chile vulnera el deber general de respetar los derechos establecido en la Convención Americana de Derechos Humanos, pues no ha adecuado el Código de Justicia Militar y sus normas complementarias, a fin de hacerlos efectivos. "Es imperiosa la necesidad de reformar la Justicia Militar, pues su estructura no solo no se adecua a la Convención Americana sobre Derechos Humanos, sino también vulnera principios fundamentales de un Estado democrático, tales como la igualdad ante la ley, y el debido proceso", ${ }^{60}$ aspecto que constatamos de modo elocuente en materia de desacato del Artículo 283 del Código de Justicia Militar, desde que se trata de un delito común, sin sujeto activo calificado y que, sin embargo, es de competencia de esta jurisdicción especial.

Luego de la condena impuesta por la Corte Interamericana de Derechos Humanos por el caso Palamara Iribarne, Luppy Aguirre escribe que el Estado de Chile informó que con fecha 26 de enero de 2006 se creó una Comisión Especial encargada de realizar y proponer una reforma integral a la justicia penal militar. En su presentación indica que dicha Comisión estaría integrada por representantes de los Ministerios del Interior, Relaciones Exteriores, Justicia y de las Fuerzas Armadas y de Orden. "Sin embargo, a la fecha -más de un año de su constitución-la Comisión no sólo no ha generado un documento que sea conocido sobre la materia, sino que, además, si bien aparece en la página del Ministerio de Justicia como proyectos pendientes, el link respectivo carece de toda información respecto a los avances de la Comisión, de la cual -al menos en el ambiente académico y de cara a la ciudadanía- ni siquiera se conoce la individualización de los miembros que la conforman". ${ }^{61}$

${ }^{58}$ Corte Interamericana de Derechos Humanos. Caso Palamara Iribarne vs Chile, sentencia de 22 de noviembre de 2005, op. cit., p. 468.

${ }^{59}$ Corte Interamericana de Derechos Humanos. Caso Palamara Iribarne vs Chile, sentencia de 22 de noviembre de 2005, op. cit., p. 469.

60 Tolosa, R., "Reforma de la Justicia Militar chilena a la luz de las consideraciones del fallo Palamara", en Revista Chilena de Derecho, vol. 34 N $^{\circ}$ 1, Santiago, 2007 pp. 139-151.

${ }^{61}$ Aguirre, L., El caso Palamara Iribarne v/s Chile, en Revista de Estudios de la Justicia, Facultad de Derecho de la Universidad de Chile, Nº 9, año 2007, Santiago, p. 286. 


\section{4.b. Desacato y libertad de expresión}

Más de una década ha transcurrido desde que el entonces senador Gabriel Valdés Subercaseaux, en mayo de 1996 celebrara ante sus pares de la Cámara Alta la condena impuesta por el máximo tribunal del país al ex ministro de la dictadura militar Francisco Javier Cuadra, como autor del delito de desacato, luego que éste sostuviera a través de una publicación de prensa que en Chile hay parlamentarios que consumen drogas.

Así, en la segunda sesión de 22 de mayo de 1996, el senador Gabriel Valdés pidió la palabra al Presidente de la Corporación, Sergio Diez Urzúa, para afirmar que en enero del año 1995, con acuerdo de los Comités, y en su calidad de Presidente del Senado de la época, inició una acción judicial en contra de don Francisco Javier Cuadra, por el delito de desacato, de acuerdo con lo dispuesto en el Artículo $\mathrm{N}^{\circ}$ 6, letra b), de la Ley de Seguridad Interior del Estado, cometido en contra de esta Corporación y de sus integrantes.

En aquella oportunidad, el senador Valdés sostuvo que la defensa del Senado fue encomendada al profesor señor Alfredo Etcheberry. "El proceso ha llegado a su fin por sentencia de la Excelentísima Corte Suprema, de 14 del mes en curso. Ella tiene notable valor jurídico, pues analiza las disposiciones legales atingentes a la difamación, la injuria, la libertad de expresión y los delitos que en su ejercicio puedan cometerse. En el caso de autos, se acreditó que se ofendió a los Parlamentarios, en abstracto, y al Senado, al que pertenecen, en forma pública y reiterada, considerándose esta acción como delito de desacato y acto reprochable". ${ }^{62}$

De este modo el máximo tribunal del país a través de un recurso de queja interpuesto por los querellantes, entre ellos la Cámara Alta, revocó la absolución pronunciada por la sala de la Ilustrísima Corte de Apelaciones de Santiago, presidida por el magistrado Carlos Cerda Fernández, la que fundamentó su decisión absolutoria en una idea del orden público íntimamente ligada con el ejercicio de los derechos humanos, incluso el derecho a criticar, y que quiso demostrar que las declaraciones de Cuadra no habían sido perjudiciales, sino al contrario, correspondían a un uso constructivo de aquel derecho, al criticar una conducta que podría llevar al Congreso y, por tanto, al conjunto de las instituciones democráticas al desprestigio. ${ }^{63}$

Hoy, con la certeza que otorga el paso del tiempo, se puede afirmar que esa victoria judicial del Senado de la República fue un verdadero triunfo a lo pirro, pues la cuna del debate nacional en lugar de resistir con ideas la crítica acerba prefirió atropellar su vocación democrática y castigar criminalmente a quien se estimó había ofendido de palabra a una institución, en virtud de normas legales que finalmente fueron en general derogadas por los gobiernos de los Presidentes Frei y Lagos, precisamente en razón de su innegable espíritu autoritario y contrario a los derechos fundamentales de la persona humana.

${ }^{62}$ http://www.senado.cl/sesiones/pags/diar/19991111134646.html. Sesión 2a , en miércoles 22 de mayo de 1996.

${ }^{63}$ Human Rights Watch, "Los límites de la tolerancia. Libertad de expresión y debate público en Chile", Ediciones LOM, Santiago, 1998, pp. 178-179. 
En el mensaje que el propio Presidente Ricardo Lagos dirigió al Congreso para iniciar la tramitación del proyecto de ley que derogó el desacato del Código Penal, expresó con claridad el fundamento de dicha abrogación, al sostener que es difícil pensar que las simples expresiones vertidas respecto a un funcionario público, sin que medie ningún peligro inminente, pudiesen significar un atentando contra ese bien jurídico protegido (estabilidad del sistema social y político). ${ }^{64}$

Ese texto agrega que la existencia de estas normas no resulta coherente con el funcionamiento de un Estado democrático moderno. No parece razonable que se otorgue a ciertos funcionarios públicos un derecho injustificado a la protección del que no gozan los demás miembros de la sociedad. Sobre todo, considerando que quienes desarrollan tareas de decisión y conducción política deben estar sujetos a un control ciudadano que se podría ver inhibido frente a la mayor severidad de las normas que sancionan el desacato. Además, impide, mediante el temor a la pena que se podría imponer por esta vía, que se desarrolle plenamente el libre debate y el ejercicio de la libertad de investigación periodística. ${ }^{65}$

En ese mismo sentido, la Comisión Interamericana de Derechos Humanos ha planteado que la aplicación de las leyes de desacato destinadas a proteger el honor de los funcionarios públicos -que actúan en carácter oficial- les otorga injustificadamente un derecho a la protección del que no disponen los demás integrantes de la sociedad. Esta distinción invierte directamente el principio fundamental de un sistema democrático que hace al gobierno objeto de controles, entre ellos, el escrutinio de la ciudadanía, para prevenir o controlar el abuso de su poder coactivo. ${ }^{66}$

Dicho órgano ha planteado que el tipo de debate político crítico, propio del sistema democrático, genera discursos duros e incluso ofensivos para quienes ocupan cargos públicos o están íntimamente vinculados a la formulación de la política pública. De allí que el ataque de quien se encuentra en posición de poder o autoridad respecto de la crítica acerba afecta la esencia de la libertad de expresión. ${ }^{67}$

En general, estos son los argumentos que han justificado el proceso de adecuación de nuestra legislación interna a la garantía que asegura la libertad de expresión, tanto en nuestra Constitución como en el sistema de justicia internacional y que, de paso, explica las diversas innovaciones legislativas de los últimos dos lustros que, con vacilaciones y de modo fragmentario, ha derogado la mayoría de las figuras de desacato de nuestro paisaje normativo.

${ }^{64}$ Mensaje N ${ }^{\circ}$ 212-347 de 26 de agosto de 2002 remitido por el Presidente de la República a la Cámara de Diputados para iniciar la tramitación del proyecto de ley que modifica el Código Penal y el Código de Justicia Militar en materia de desacato y que dio origen a la Ley 20.048.

${ }^{65}$ Ibid, cita $\mathrm{N}^{\circ} 67$.

66 Informe Anual de la Comisión Interamericana de Derechos Humanos, 1994, p. 218.

${ }^{67}$ Citado por el profesor Humberto Nogueira Alcalá, en su obra El Derecho a la Libertad de Opinión e Información y sus Límites, versión disponible en el portal electrónico de Lexis Nexis, sección doctrina, área jurídica. 
Entre esas iniciativas, se puede mencionar: La ley $19.733,{ }^{68}$ conocida como Ley de Prensa, derogó de la Ley de Seguridad Interior del Estado el Artículo 6 b) que contenía figuras agravadas de desacato y que castigaba como delitos contra el orden público y la integridad del Estado la injuria, la calumnia y la difamación contra altas autoridades de la Nación; las leyes $20.048^{69}$ y $20.064,{ }^{70}$ la primera de las cuales derogó la figura de desacato en su modalidad de injurias y calumnias del Código Penal y la segunda que ajustó a esos términos el Artículo 417 del Código de Justicia Militar que castigaba penalmente al que ofendiere o injuriare de palabra o por escrito o por cualquier otro medio a funcionarios de Carabineros e Investigaciones.

Cuesta, entonces, comprender por qué hoy, luego de la derogación del delito de desacato del catálogo punitivo, un atentado contra el honor del Presidente de la República sólo confiere al ofendido acción penal privada para perseguir las injurias o calumnias de que ha sido víctima y, en cambio, la legislación especial mantiene a los uniformados el privilegio de disponer de la acción penal pública para reaccionar contra quien de palabra o por escrito lesione, ya no sólo su propia honra, sino también la de las instituciones armadas a las que pertenece, tal como lo prescriben los artículos 283 y 284 del Código de Justicia Militar.

Este necesario ajuste del Código de Justicia Militar es una deuda pendiente con el Estado de Derecho. Si bien por sí sola no cambiará necesariamente nuestra acendrada cultura autoritaria, ${ }^{71}$ al menos servirá para sentar las bases normativas que permitan abogar por la construcción de una sociedad más liberal y democrática.

\section{BIBLIOGRAFÍA}

Aguirre, L., "Justicia militar. Una mirada en cifras", en Mera Figueroa, J. (Editor), Justicia militar y estado de derecho, Cuadernos de Análisis Jurídico de la Universidad Diego Portales, Santiago, 1998.

Aguirre, L., El caso Palamara Iribarne v/s Chile., en Revista de Estudios de la Justicia, Facultad de Derecho de la Universidad de Chile, No 9, año 2007.

Astrosa, R., Derecho Penal Militar, 2a ed., Ed. Jurídica de Chile, Santiago, 1974.

Astrosa, R., Código de Justicia Militar comentado, $3^{\mathrm{a}}$ ed., Ed. Jurídica de Chile, Santiago, 1985.

68 Publicada el 4 de junio de 2001.

69 Publicada el 31 de agosto de 2005.

${ }^{70}$ Publicada el 29 de septiembre de 2005.

${ }^{71}$ La Iltma. Corte de Apelaciones de Puerto Montt en la causa Rol Ingreso de Corte No 205-2007, de 22 de mayo de 2007, rechazó una acción de amparo presentada por un particular que fue detenido por supuestas ofensas a Carabineros. El Ministerio Público de la Región de Los Lagos en investigación RUC 0600574426-K seguida ante el Tribunal de Letras, Garantía y Familia de Calbuco con fecha 21 de diciembre de 2006 inició la persecución oficial en contra de un defensor penal público, por el solo hecho de representar verbalmente a los funcionarios de Investigaciones la ilegalidad de los interrogatorios a los cuales sometieron a una imputada en la Fiscalía Local de Calbuco. 
Bovino, A., "La justicia militar y juzgamiento de civiles", en Mera, Jorge (Editor), Justicia militar y estado de derecho, Cuadernos de Análisis Jurídico, Escuela de Derecho de la Universidad Diego Portales, Santiago, 1998.

Couso, J., "Competencia de la justicia militar. Una perspectiva político-criminal", en Mera, Jorge (Editor), Hacia una Reforma de la Justicia Militar, Cuadernos de Análisis Jurídico, Escuela de Derecho de la Universidad Diego Portales, Santiago, 2002.

Horvitz, M. I., "La justicia militar: justificación, competencia y organización en el derecho comparado. Los principios de independencia e imparcialidad en la organización de los tribunales militares chilenos", en Mera Figueroa, J. (Editor), Justicia militar y estado de derecho, Cuadernos de Análisis Jurídico de la Universidad Diego Portales, Santiago, 1998.

Human Rights Watch, "Los límites de la tolerancia libertad de expresióny debate público en Chile", Ediciones LOM, Santiago, 1998.

Informe Anual de la Comisión Interamericana de Derechos Humanos, 1994.

Luzón PeÑa, D.-M., "Curso de Derecho Penal", Tomo I, primera reimpresión, Ed. Universitas, Madrid, 1999.

Mera, J., "Razones justificatorias y ámbito de la jurisdicción penal militar en tiempo de paz", en Mera Figueroa, J. (Editor), Justicia militar y estado de derecho, Cuadernos de Análisis Jurídico de la Universidad Diego Portales, Santiago, 1998.

Mera, J., "La Parte Especial del Derecho Penal Militar Chileno" en Mera Figueroa, J. (Editor), Hacia una Reforma de la Justicia Militar, Cuadernos de Análisis Jurídico de la Universidad Diego Portales, Santiago, octubre, 2002.

Mera, J., "Bases programáticas para la reforma integral del derecho penal militar chileno", Informe de Investigación $N^{\circ} 16$, Centro de Investigaciones Jurídicas, Facultad de Derecho de la Universidad Diego Portales, Santiago, 2003.

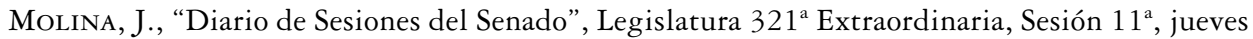
8 de noviembre de 1990, publicación oficial, Valparaíso.

Politoff, S., "Derecho Penal", Tomo I, Ed. Jurídica Conosur, 2a Ed, Santiago, 2001.

Rodríguez, A, "Delitos militares y jurisdicción militar", en Mera Figueroa, J. (Editor), Justicia militar y estado de derecho, Cuadernos de Análisis Jurídico de la Universidad Diego Portales, Santiago, 1998.

Tolosa, R., "Reforma de la Justicia Militar chilena a la luz de las consideraciones del fallo Palamara", en Revista Chilena de Derecho, vol. $34 \mathrm{~N}^{\circ}$ 1, Santiago, 2007.

Zaffaroni, R. E. y Cavallero, R., "Derecho Penal Militar", Ariel, Buenos Aires, 1980. 